\title{
Slovak natural zeolites as a suitable medium for antibiotics elimination from wastewater
}

\author{
Petra Szabová, Michaela Plekancová, Nikolas Gróf, Igor Bodík \\ Department of Environmental Engineering, Faculty of Chemical and Food Technology, \\ Slovak University of Technology, Radlinského 9, 81237 Bratislava, Slovak Republic \\ petaszabova@gmail.com, igor.bodik@stuba.sk
}

\begin{abstract}
Pharmaceuticals are one of the most used compounds present in various environmental compartments. Due to their high consumption and possible unhealthy effect on ecosystems, pharmaceuticals have been identified as "emerging organic contaminants". Since these compounds have medium to high polarity, they end up in the water compartment after being used. This work deals with the sorption of three pharmaceutical substances from the therapeutic group of antibiotics. Specifically we have focused on Azithromycin, Clarithromycin and Erythromycin. Three fractions of the natural Slovak zeolites $(200 \mu \mathrm{m}$, $0.5-1 \mathrm{~mm}$ and $1.5-2 \mathrm{~mm}$ ) were used as the sorption medium. Experimental results have proven very effective sorption of antibiotics by zeolites. Azithromycin removal of over $99 \%$ for all three zeolite fractions from wastewater treatment plant Stupava and wastewater treatment plant Devínska Nová Ves was achieved. Clarithromycin removal of $79 \%$ for fraction $1-2.5 \mathrm{~mm}, 87.3 \%$ for fraction $0.5-1 \mathrm{~mm}$ and of $99.8 \%$ for fraction $200 \mu \mathrm{m}$ from the effluent of wastewater treatment plant Stupava was observed. Erythromycin removal of $31.3 \%$ for fraction $1-2.5 \mathrm{~mm}, 66.9 \%$ for fraction $0.5-1 \mathrm{~mm}$ and of $94.7 \%$ for fraction $200 \mu \mathrm{m}$ from effluent of wastewater treatment plant Stupava was measured. More than $95 \%$ of Clarithromycin and Erythromycin were eliminated from the effluent of wastewater treatment plant Devínska Nová Ves. The highest elimination percentage was observed for the smallest zeolite fraction due to the highest specific surface area.
\end{abstract}

Keywords: antibiotics, pharmaceuticals, wastewater, zeolites.

\section{Introduction}

Intensive research on pharmaceuticals in the environment started about 25 years ago. Since then, a vast amount of literature has been published. The input and presence of active pharmaceutical ingredients and their fate in the environment have been of high interest (Kümmerer, 2009). The release of antibiotics is becoming of considerable concern due to their negative effects not only on the environment but also on human health ( $\mathrm{Lu}$ et al., 2014). Antibiotics are antimicrobial agents of different chemical structures characterized by selective toxicity to certain types of bacteria. Antibiotics as pharmaceuticals are among the most prescribed medicines by general practitioners not only in Slovakia but also in the world. In the US, 262.5 million antibiotic packs (842 prescriptions per 1000 persons) were prescribed in 2011. In 2016, Slovak doctors prescribe 718 packs antibiotic per 1000 inhabitants (Šušková, 2017).

Erythromycin is an antibiotic used for the treatment of some bacterial infections. Azithromycin is used for the treatment of a number of bacterial infections for example: ear infections, strep throat, pneumonia, diarrhea, and certain other intestinal infections (Sylvester et al., 2009). Clarithromycin is used to treat various bacterial infections as: pneumonia, skin infections, Helicobacter pylori infection, and Lyme disease; it can be taken by mouth as a pill or liquid (Sylvester et al., 2009).
Many studies confirm that pharmaceuticals appeared in high concentration in wastewater treatment plants (WWTPs) worldwide. Concentration of clarithromycin in the influent of WWTPs is from 330 to $600 \mathrm{ng} / \mathrm{l}$ and in the effluent of WWTPs it ranges from 150 to $460 \mathrm{ng} / \mathrm{l}$ (Göbel et al., 2005). Erythromycin in WWTPs influent ranges between 140-10 $020 \mathrm{ng} / \mathrm{l}$ and in WWTPs effluent between 23-2 $700 \mathrm{ng} / \mathrm{l}$ (Kasprzyk-Hordern, Dinsdale and Guwy, 2009). Azithromycin in WWTPs influent ranges from 90 to $380 \mathrm{ng} / \mathrm{l}$ and in the effluent from 40 to $380 \mathrm{ng} / \mathrm{l}$ (Göbel et al., 2005).

The adsorption technology in a real WWTP is designed according to (Keysers et al., 2015), after the settlement tank, two separate lines for ozonation and sorption are located; they can be operated as single lines or in sequence (ozonation with subsequent sorption). Regeneration of zeolites can be based on thermal treatment, where adsorbed molecules are volatilized and/or oxidized by heating. Alternatively, the solvent extraction of entrapped molecules is considered as another efficient technique. Other methods include photochemical, biological, vacuum, electri$\mathrm{cal} /$ electrochemical, and supercritical fluid treatment, as well as microwave and ultrasound methods (Braschi et al., 2016).

The aim of this work was to eliminate selected antibiotics from effluent of wastewater treatment plants by means of sorption processes. For sorption tests, 
Slovak natural zeolites from Zeocem a.s. (Košice, Slovakia) were used.

\section{Materials and methods}

Laboratory sorption tests were realized with Slovak natural zeolites from Zeocem a.s. (Košice, Slovakia) and with effluents from two municipal WWTPs. In the effluent samples from WWTP Stupava and WWTP Devínska Nová Ves, a wide spectrum of pharmaceuticals from different therapeutic groups were analyzed. As antibiotics are the most prescribed pharmaceuticals in the Slovak Republic, three compounds for our research were selected: azithromycin (AZI), erythromycin (ERY) and clarithromycin (CLA).

\section{Pharmaceuticals analysis}

The samples were filtered through a $0.45 \mu \mathrm{m}$ cellulose membrane filter. Before HPLC/MS/MS analysis, a mixture of isotopes labelled internal standards was added to $10 \mathrm{ml}$ of the sample. For pharmaceutical products detection, SPE liquid chromatography combined with a hybrid quadrupole - Orbitrap, and a high resolution detector was used (Grabic et al., 2012). Table 1 summarizes basic information on the monitored antibiotics.

\section{Characteristics of Slovak natural zeolites}

Zeolites are natural or synthetic aluminosilicates of ordered arrangements of $\mathrm{SiO}_{4}$ and $\mathrm{AlO}_{4}$ tetrahedra. Isomorphic substitution of silicon $(\mathrm{Si})$ by aluminum
(Al) creates an overall negative charge which is compensated by cations, for example $\mathrm{Na}^{+}, \mathrm{K}^{+}, \mathrm{Ca}^{2+}$ and $\mathrm{Mg}^{2+}$, providing zeolites with the properties of cationic exchangers. Natural zeolites and less pure forms of synthetic zeolites, such as those derived from fly ash, find limited applications in wastewater treatment, where high selectivity and specificity are not an issue. The general formula of a zeolite is $\mathrm{M}_{\mathrm{e} 2 / \mathrm{n}} \mathrm{O} \cdot \mathrm{Al}_{2} \mathrm{O}_{3} \cdot \mathrm{xSiO}_{2} \cdot \mathrm{yH}_{2} \mathrm{O}$, where, $\mathrm{M}_{\mathrm{e}}$ is any alkali or alkaline earth atom, $\mathrm{n}$ is the charge on that atom, $\mathrm{x}$ is the number of Si tetrahedron varying from 2 to 10 , and $y$ is the number of water molecules varying from 2 to 7 (Sun et al., 2017).

Extensive possibilities of zeolites are mainly due to their specific physicochemical properties:

- high ion exchange selectivity

- reversible hydration and dehydration

- high gas sorption capacity

- high thermostability

- resistance to aggressive media (Zeocem a.s., 2016)

Sorption tests were carried out with $10 \mathrm{~g}$ of three zeolite fractions (200 $\mu \mathrm{m}$; 0.5-1 $\mathrm{mm} ; 1-2.5 \mathrm{~mm}$ ) and $200 \mathrm{ml}$ of WWTPs effluent. Sorption time was

Tab. 2. Basic properties of tested zeolites (Zeocem a.s., 2016).

\begin{tabular}{lll}
\hline Fraction of zeolites & & Specific surface area \\
\hline $200 \mu \mathrm{m}$ & Powder & $53-55 \mathrm{~m}^{2} / \mathrm{g}$ \\
$0.5-1 \mathrm{~mm}$ & Fine sand & $44-46 \mathrm{~m}^{2} / \mathrm{g}$ \\
$1-2.5 \mathrm{~mm}$ & Coarse sand & $40-42 \mathrm{~m}^{2} / \mathrm{g}$ \\
\hline
\end{tabular}

Tab. 1. Basic characteristics of pharmaceuticals.

\begin{tabular}{|c|c|c|c|c|c|}
\hline Pharmaceutical & $\begin{array}{c}\text { Molecular } \\
\text { weight }(\mathrm{g} / \mathrm{mol})\end{array}$ & $\mathrm{pKa}$ & Charge at pH 7 & Log Kow & References \\
\hline azithromycin & 784.99 & $\begin{aligned} \mathrm{pKa}_{1} & =8.7 \\
\mathrm{pKa}_{2} & =9.5\end{aligned}$ & Positive & $0.44-3.16$ & Xian et al., 2015 \\
\hline clarithromycin & 747.95 & 8.99 & Positive & $3.18 ; 3.16$ & Verlicchi et al., 2012a \\
\hline erythromycin & 737.93 & $8.88-8.9$ & Positive & $\begin{array}{c}2.5 \\
3.06\end{array}$ & $\begin{array}{l}\text { Jones et al., } 2002 \\
\text { Verlicchi et al., } 2012 \text { a }\end{array}$ \\
\hline
\end{tabular}
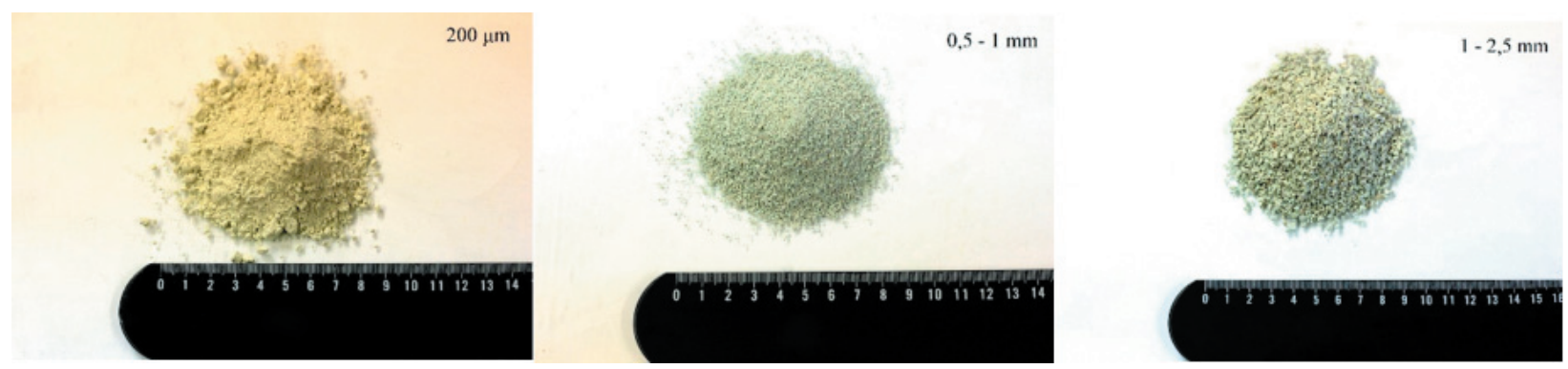

Fig. 1. Zeolite fractions. 
30 min. Subsequently, samples were taken and sent for drug analysis. Table 2 summarizes basic properties of the individual fractions.

\section{Results and discussion}

Since 2014, monitoring of pharmaceuticals in wastewater has been carried out at the Department of Environmental Engineering, Faculty of Chemical and Food Technology, Slovak University of Technology in Bratislava. In the first step, monitoring of selected antibiotics was carried out at 15 Slovak WWTPs. Table 3 summarizes average concentration of antibiotics in the individual stages of Slovak WWTPs. These data show that removal of antibiotics is very low; specifically, removal of ERY and AZI is only $32 \%$ and $65 \%$, respectively. Although the removal of CLA is relatively high $93 \%$, the total effluent concentration is very high (258 $\mathrm{ng} / \mathrm{l})$. Real effluent concentrations of all monitored antibiotics are higher than $200 \mathrm{ng} / \mathrm{l}$, so adding a tertiary treatment step to eliminate these residual concentrations is strongly advised. Elimination of pharmaceuticals from water is very important as they negatively affect fish and other living organisms. Some studies indicate mutations in fish due to drug accumulation in water (Mimeault et al., 2005).

\section{Wastewater treatment plant Stupava}

In wastewater treatment plant Stupava, wastewater from 13000 p.e. is treated but its capacity is up to 18000 p.e. WWTP Stupava consists of a mechanical and a biological (pre-denitrification, nitrification) stage, and sludge is aerobically stabilized. Monitor- ing of the selected antibiotics shows that the drugs are present in the influent at hundreds of $\mathrm{ng} / \mathrm{l}$ (Table 4) and their removal is not satisfying.

Elimination of selected antibiotics is very high but effluent concentration is also high. For example, removal of CLA was $94 \%$ but effluent concentration was $100 \mathrm{ng} / \mathrm{l}$, which indicates the need to add a tertiary treatment step.

Tab. 4. Average concentration of pharmaceuticals in WWTP Stupava influents and effluents and their removal efficiency.

\begin{tabular}{lrcc}
\hline Pharmaceuticals & $\begin{array}{c}\text { Influent } \\
\text { ng/l }\end{array}$ & $\begin{array}{c}\text { Effluent } \\
\text { ng/l }\end{array}$ & $\begin{array}{c}\text { Removal } \\
\%\end{array}$ \\
\hline azithromycin & 430 & 180 & 58 \\
clarithromycin & 1700 & 100 & 94 \\
erythromycin & 390 & 63 & 84 \\
\hline
\end{tabular}

Concentrations of AZI, CLA and ERY of $520 \mathrm{ng} / 1$ AZI, $2200 \mathrm{ng} / \mathrm{l} \mathrm{CLA}$ and $16 \mathrm{ng} / 1 \mathrm{ERY}$ were detected in WWTP Stupava effluents. Table 5 summarizes data measured after the sorption test with individual zeolite fractions run for 30 minutes. AZI was effectively (over $99 \%$ ) removed by all three fractions. CLA was removed $(79.1 \%)$ using the largest zeolite fraction $(1-2.5 \mathrm{~mm})$, and the efficiency of the removal increased with the gradual reduction of the fraction. With the finest $200 \mu \mathrm{m}$ fraction, CLA removal was above $99 \%$. The lowest elimination of the selected antibiotics was achieved for ERY, the elimination effect was $31 \%$ with the largest fraction $(1-2.5 \mathrm{~mm})$, which is significantly lower than that for AZI and CLA. ERY was most effectively removed using the $200 \mu \mathrm{m}$ fraction $(94.7 \%)$. The

Tab. 3. Average sewage concentration in individual WWTPS stages from long term monitoring during last 12 months.

\begin{tabular}{lccccc}
\hline Pharmaceuticals & $\begin{array}{c}\text { Influent } \\
\text { ng/l }\end{array}$ & $\begin{array}{c}\text { Primary } \\
\text { sedimentation tank } \\
\text { ng/l }\end{array}$ & $\begin{array}{c}\text { Removal after primary } \\
\text { sedimentation tank } \\
\%\end{array}$ & $\begin{array}{c}\text { Total effluent } \\
\text { ng/l }\end{array}$ & $\begin{array}{c}\text { Total removal } \\
\text { of antibiotics } \\
\%\end{array}$ \\
\hline azithromycin & 598 & 387 & 35 & 208 & 65 \\
clarithromycin & 3870 & 842 & 78 & 258 & 93 \\
erythromycin & 296 & 177 & 40 & 202 & 32 \\
\hline
\end{tabular}

Tab. 5. Measured data from WWTP Stupava after 30 min of sorption tests.

\begin{tabular}{lccccccc}
\hline Pharmaceuticals & $\begin{array}{c}\text { Effluent } \\
\mathrm{ng} / \mathrm{l}\end{array}$ & $\begin{array}{c}1-2.5 \mathrm{~mm} \\
\text { zeolite } \\
\mathrm{ng} / \mathrm{l}\end{array}$ & $\begin{array}{c}\text { Removal } \\
\%\end{array}$ & $\begin{array}{c}0.5-1 \mathrm{~mm} \\
\text { zeolite } \\
\mathrm{ng} / \mathrm{l}\end{array}$ & $\begin{array}{c}\text { Removal } \\
\%\end{array}$ & $\begin{array}{c}200 \mu \mathrm{um} \\
\text { zeolite } \\
\mathrm{ng} / \mathrm{l}\end{array}$ & $\begin{array}{c}\text { Removal } \\
\%\end{array}$ \\
\hline azithromycin & 520 & 3.2 & 99.4 & 2.2 & 99.6 & 2.4 & 99.5 \\
clarithromycin & 2200 & 460 & 79.1 & 280 & 87.3 & 4 & 99.8 \\
erythromycin & 16 & 11 & 31.3 & 5.3 & 66.9 & 0.85 & 94.7 \\
\hline
\end{tabular}


results show that the highest sorption efficiency was achieved with the smallest zeolite fraction; which confirms the fact that smaller fraction of zeolites and larger specific surface provide better sorption.

Wastewater treatment plant Devínska Nová Ves (DNV) This wastewater treatment plant currently treats 45000 p.e. of wastewater, but its capacity is up to 76000 p.e. WWTP DNV consists of a mechanical stage and a biological (nitrification, denitrification and bio-P elimination) stage, sludge is also anaerobically stabilized and generated biogas is energetically recovered. Monitoring showed that the selected antibiotics are present in the influent in hundreds of ng/l (Table 6). From the results it is evident that elimination of the selected antibiotics in WWTP Devínska Nová Ves is very low, for example average effluent concentration of CLA is $615 \mathrm{ng} / \mathrm{l}$. The highest removal efficiency was observed for ERY (45\%), however, effluent concertation was $16 \mathrm{ng} / \mathrm{l}$.

Tab. 6. Influents and effluents of WWTP Devínska Nová Ves and their removal during last 12 months.

\begin{tabular}{lccc}
\hline Pharmaceuticals & $\begin{array}{c}\text { Influent } \\
\mathrm{ng} / \mathrm{l}\end{array}$ & $\begin{array}{c}\text { Effluent } \\
\mathrm{ng} / \mathrm{l}\end{array}$ & $\begin{array}{c}\text { Removal } \\
\%\end{array}$ \\
\hline azithromycin & 780 & 610 & 22 \\
clarithromycin & 820 & 615 & 25 \\
erythromycin & 29 & 16 & 45 \\
\hline
\end{tabular}

Subsequently, a second experiment was carried out to confirm the high removal of antibiotics with wastewater from WWTP Devínska Nová Ves. The observed substances were detected at concentrations of $300 \mathrm{ng} / \mathrm{l}$ of AZI, $440 \mathrm{ng} / \mathrm{l}$ of CLA and $37 \mathrm{ng} / \mathrm{l}$ of ERY. Table 7 summarizes concentrations of antibiotics in the WWTP effluents and concentrations after sorption on zeolites.

The second experiment confirmed the findings of the Stupava wastewater experiment. The removal of all drugs was above $90 \%$.

The removal efficiency of all monitored antibiotics was above $95 \%$ for all zeolite fractions. More than 99 \% of AZI were removed from both WWTPs with each of the three zeolite fractions. CLA concentration was fivefold lower in the effluent from WWTP
Devínska Nová Ves than in that from WWTP Stupava. CLA removal in WWTP Devínska Nová Ves was $19 \%$ higher for the zeolite fraction of $1-2.5 \mathrm{~mm}$ and $11 \%$ for the $0.5-1 \mathrm{~mm}$ fraction compared to WWTP Stupava. For the ultra-fine-grained zeolite fraction, CLA elimination was comparable with the results from Stupava. The highest differences in the elimination of antibiotics were observed for ERY. From the WWTP Devínska Nová Ves effluent, $64 \%$ more ERY were removed using zeolites than from the WWTP Stupava effluent (fraction $1-2.5 \mathrm{~mm}$ ). This difference may be related to different wastewater composition as well as to different concentrations of other drugs that can preferably be sorbed onto the zeolites. This fact was also confirmed by the fraction $0.5-1 \mathrm{~mm}$, where the difference in ERY elimination was $31 \%$ between WWTP Devínska Nová Ves $(97.5 \%)$ and WWTP Stupava $(66.9 \%)$. The ultra-fine-grained zeolite fraction showed the highest ERY removal efficiency and was approximately the same for both effluents.

Oh et al. (2016) found that if $\mathrm{pH}<\mathrm{pKa}$, sorption is most effective, $\mathrm{pH}=\mathrm{pKa}$ shows partial sorption and $\mathrm{pH}>\mathrm{pKa}$ minimal sorption. The measured results confirm that $\mathrm{pH}$ of the WWTP Stupava effluent was 6.85 and all studied drugs have pKa of above 8 and a positive charged molecule at $\mathrm{pH}=7$ (see Table 1). All tested antibiotics have a positive charged molecule at $\mathrm{pH}=7$ while zeolites have a negative charged crystal grid (Frankovská et al., 2010); thus antibiotics and zeolites interact with each other, which promotes their sorption. Measured $\mathrm{pH}$ in the effluent of WWTP Devínska Nová Ves was 7.01, which meets the condition of good sorption at $\mathrm{pH}<\mathrm{pKa}$. Based on the results, zeolite sorption is an effective way of eliminating antibiotics from wastewater in a post-treatment step.

\section{Conclusions}

The work was focused on finding sorption properties of selected antibiotics. High concentrations of azithromycin, clarithromycin and erythromycin were found in the effluents from WWTP Stupava and WWTP Devínska Nová Ves. Three zeolite fractions with different specific surfaces were tested. These sorption tests showed their potential for

Tab. 7. Measured data from WWTP Devínska Nová Ves.

\begin{tabular}{|c|c|c|c|c|c|c|c|}
\hline Pharmaceuticals & $\begin{array}{c}\text { Effluent } \\
\mathrm{ng} / \mathrm{l}\end{array}$ & $\begin{array}{c}1-2.5 \mathrm{~mm} \\
\text { zeolite } \\
\mathrm{ng} / \mathrm{l}\end{array}$ & $\begin{array}{c}\text { Removal } \\
\%\end{array}$ & $\begin{array}{c}0.5-1 \mathrm{~mm} \\
\text { zeolite } \\
\mathrm{ng} / \mathrm{l}\end{array}$ & $\begin{array}{c}\text { Removal } \\
\%\end{array}$ & $\begin{array}{c}200 \mu \mathrm{m} \\
\text { zeolite } \\
\mathrm{ng} / \mathrm{l}\end{array}$ & $\begin{array}{c}\text { Removal } \\
\%\end{array}$ \\
\hline azithromycin & 300 & 0.89 & 99.7 & 0.62 & 99.8 & 0.92 & 99.6 \\
\hline clarithromycin & 440 & 9.4 & 97.9 & 8.1 & 98.2 & 3.6 & 99.2 \\
\hline erythromycin & 37 & 1.7 & 95.4 & 0.91 & 97.5 & 0.57 & 98.5 \\
\hline
\end{tabular}


eliminating selected drugs from the wastewater treatment plant. The highest rate of antibiotic removal was observed using zeolites with the highest specific surface, i.e., the smallest fraction $200 \mu \mathrm{m}$ (WWTP Stupava: AZI 99.5 \%, CLA 99.8 \% ERY 94.7 \%, WWTP Devínska Nová Ves: AZI 99.6 \%, CLA 99.2 \% ERY $98.5 \%$ ). The results prove that zeolites can be used as sorption material for pharmaceuticals removal from wastewater; however, due to problematic handling of the finest dust fractions in real conditions, using the middle fraction of zeolites is recommended as their antibiotic removal efficiency is approximately the same.

\section{Acknowledgement}

This work was supported by the Slovak Research and Development Agency under the contract No APVV 0119. 17. The authors thank the company Zeocem a.s. (Košice, Slovakia) for providing zeolite samples.

\section{References}

Braschi I et al. (2016) Physicochemical regeneration of high silica zeolite $\mathrm{Y}$ used to clean-up water polluted with sulfonamide antibiotics, Journal of Environmental Sciences. Elsevier, 43, pp. 302-312. doi: 10.1016/J. JES.2015.07.017.

Frankovská J et al. (2010) Atlas sanačných metód environmentálnych zátaží. Štátny geologický ústav Dionýza Štúra, Bratislava.

Göbel A et al. (2005) Extraction and determination of sulfonamides, macrolides, and trimethoprim in sewage sludge, Journal of Chromatography A. Elsevier, 1085(2), pp. 179-189. doi: 10.1016/J. CHROMA.2005.05.051.

Grabic R et al. (2012) Multi-residue method for trace level determination of pharmaceuticals in environmental samples using liquid chromatography coupled to triple quadrupole mass spectrometry, Talanta. Elsevier, 100, pp. 183-195. doi: 10.1016/J.TALANTA.2012.08.032.
Kasprzyk-Hordern B, Dinsdale RM and Guwy AJ (2009) The removal of pharmaceuticals, personal care products, endocrine disruptors and illicit drugs during wastewater treatment and its impact on the quality of receiving waters, Water Research. Pergamon, 43(2), pp. 363-380. doi: 10.1016/J.WATRES.2008.10.047.

Keysers CH, Grünebaum T, Thöle D, Pinnekamp J (2013) Removal of pharmaceuticals in municipal wastewater treatment plants, Proc. from the $8^{\text {th }}$ IWA Specialist Conference on Assessment and Control of Micropollutants/Hazardous Substances in Water, Zurich, Switzerland.

Kümmerer K (2009) The presence of pharmaceuticals in the environment due to human use-present knowledge and future challenges, Journal of Environmental Management. Academic Press, 90(8), pp. 2354-2366. doi: 10.1016/J.JENVMAN.2009.01.023.

Lu X et al. (2014) Long-term effect of the antibiotic cefalexin on methane production during waste activated sludge anaerobic digestion, Bioresource Technology. Elsevier, 169, pp. 644-651. doi: 10.1016/J. BIORTECH.2014.07.056.

Mimeault C et al. (2005) The human lipid regulator, gemfibrozil bioconcentrates and reduces testosterone in the goldfish, Carassius auratus, Aquatic Toxicology. Elsevier, 73(1), pp. 44-54. doi: 10.1016/J. AQUATOX.2005.01.009.

Sun K et al. (2017) Sorption and retention of diclofenac on zeolite in the presence of cationic surfactant, Journal of Hazardous Materials. Elsevier B.V., 323, pp. 584-592. doi: 10.1016/j.jhazmat.2016.08.026.

Šušková T (2017) Takmer 4 milióny antibiotík. Available at: https://zivotbezantibiotik.sk/rok-2016-takmer-4miliony-antibiotik (Accessed: 11 March 2019).

Sylvester RK et al. (2009) A hospice-based advanced pharmacy experience, American Journal of Pharmaceutical Education, 73(3), pp. 1-4. doi: 10.5688/ aj730344.

Zeocem a.s. (2016) Čo je Zeolit - Klinoptilolit. Available at: https://www.zeocem.com/sk/zeolit (Accessed: 20 March 2019). 